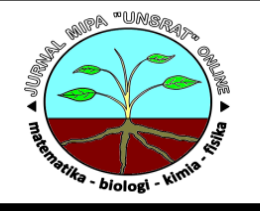

\title{
Penggulungan Daun Pada Padi Lokal Sulut Saat Kelkurangan Air
}

\author{
Audry Agatha Lenaka*, Nio Song Aia, Feky R. Mantiria, Susan Mambua \\ aJurusan Biologi, FMIPA, Unsrat, Manado
}

KATA KUNCI

Kekeringan

Penggulungan Daun

Padi lokal Sulut
A B S T R A K

Ketersediaan air merupakan salah satu faktor pembatas produksi padi di Indonesia. Kajian sifat tahan kering pada padi lokal Sulawesi Utara (Sulut) perlu dilakukan, dalam upaya mendukung tercapainya tujuan strategis meningkatkan kemampuan wilayah Sulawesi untuk menjadi pilar ketahanan pangan nasional. Penelitian ini dilakukan untuk mengevaluasi sifat tahan kering pada empat varietas padi local Sulut (Burungan, Superwin, Temo dan Ombong) pada saat kekurangan air berdasarkan karakter penggulungan daun. Setelah 14 hari perlakuan, skor penggulungan daun pada tanaman yang diairi berkisar 3-4, sedangkan pada tanaman yang tidak diairi rata-rata 9. Pada perlakuan tidak diairi skor penggulungan daun terendah pada Superwin $(7,26)$ dibandingkan pada Burungan $(8,86)$, Temo $(8,57)$ dan Ombong $(8,85)$. Berdasarkan karakter skor penggulungan daun, sifat tahan kering Superwin lebih besar dibandingkan dengan ketiga padi lokal Sulut lainnya, sehingga varietas ini potensial untuk ditanam di daerah kekurangan air.

\begin{tabular}{ll}
\hline K E Y W O R D S & A B S T R A C T \\
\cline { 2 - 3 } $\begin{array}{l}\text { Drought } \\
\text { Leaf rolling }\end{array}$ North Sulawesi local rice & $\begin{array}{l}\text { Water availability is one factor limiting rice production in Indonesia. } \\
\text { important to elevate Sulawesi capability as food security supporter. This }\end{array}$ \\
study was conducted to evaluate drought resistance in four local rice \\
cultivars (Burungan, Superwin, Temo and Ombong) under water deficit \\
condition based on the leaf rolling score. After 14 days of treatment, mean \\
of leaf rolling score in well-watered plants was 3-4, whereas in water \\
deficit plants was 9. Under water deficit, Superwin had the lowest score \\
(7.26) compared with Burungan (8.86), Temo (8.57), and Ombong (8.85). \\
Based on the leaf rolling score character, drought resistance in Superwin \\
was larger than the other 3 local rice cultivars, so that Superwin was \\
potential to be cultivated in the water limited area.
\end{tabular}

TERSEDIA ONLINE

25 Juli 2014

\section{Pendahuluan}

Ketersediaan air merupakan pembatas utama pertumbuhan tanaman. Produksi pertanian di Indonesia, termasuk di Sulawesi Utara, menurun akibat musim kemarau yang berkepanjangan. Dalam kurun waktu tahun 2001-2006 kekeringan memberikan dampak yang merugikan pada lahan padi seluas 29.222 ha dan lahan yang mengalami puso akibat kekeringan mencapai 3.872 ha (Purwani, 2006).

Lingkungan yang dapat menimbulkan cekaman pada tanaman dinamakan lingkungan yang ekstrim. Kondisi saat sel tanaman telah kehilangan air dan mempunyai tekanan turgor yang lebih rendah daripada nilai maksimumnya dinamakan kekeringan akibat kekurangan air (Darusman et al., 1991; Filter dan Hay, 1994).

\footnotetext{
*Corresponding author: Jurusan Biologi FMIPA UNSRAT, Jl. Kampus Unsrat, Manado, Indonesia 95115; Email address: audreylenak@yahoo.com Published by FMIPA UNSRAT (2014)
} 


\begin{abstract}
Proses pelayuan yang mengakibatkan penggulungan daun merupakan salah satu mekanisme tanaman menghindari kekeringan atau drought avoidance. Penggulungan daun berkaitan dengan kemampuan penyesuaian laju transpirasi untuk mempertahankan potensial air daun tetap tinggi pada saat kekurangan air. Daun yang menggulung menyebabkan luas permukaan daun yang tak terlindung menjadi lebih kecil sehingga transpirasi menurun. Penggulungan daun mengakibatkan penurunan indeks luas daun dan tingkat penerimaan cahaya yang selanjutnya akan menurunkan laju fotosintesis (Bouman dan Tuong, 2001; Kurniasih dan Wulandhany, 2009).
\end{abstract}

Penggulungan daun berkaitan erat dengan anatomi daun dan terjadi karena proses pengkerutan bulliform cell atau sel kipas. Sel kipas juga berperan dalam membuka dan menutupnya daun dalam proses penggulungan daun (Fahn, 1990; Zou et al., 2011). Sel ini akan kehilangan air melalui transpirasi lebih cepat daripada sel epidermis lainnya. Saat terjadi kekurangan air, tekanan turgor pada sel ini menurun dan memungkinkan daun menggulung ke dalam (Salisbury and Ross, 1992; Kurniasih dan Wulandhany, 2009). Beberapa indikator tanaman yang mengalami kekeringan akibat kekurangan air dapat ditinjau dari aspek fisiologi, anatomi, dan morfologi, tetapi kajian hal tersebut masih kurang dilakukan pada padi lokal Sulut. Oleh sebab itu dilakukan penelitian yang bertujuan untuk menentukan sifat tahan kering pada padi lokal Sulut (Burungan, Superwin, Temo dan Ombong) berdasarkan tingkat penggulungan daun dan menginformasikan varietas padi lokal Sulut yang tahan kering dan potensial untuk ditanam pada saat musim kemarau.

\section{Metode}

Penelitian ini dilaksanakan pada bulan Maret sampai Mei 2014 selama 4 minggu di rumah kaca di Kelurahan Tingkulu, Manado, Sulawesi Utara dan Laboratorium Ekologi Jurusan Biologi FMIPA Universitas Sam Ratulangi. Bahan penelitian yang digunakan ialah benih padi varietas lokal Sulut yaitu Burungan, Superwin, Temo dan Ombong. Variabel bebas dalam penelitian ini adalah perlakuan pengairan, yaitu diairi sampai kapasitas lapang dan tidak diairi sama sekali, sedangkan variabel terikatnya adalah penggulungan daun

Tahapan kerja dalam penelitian ini meliputi pemilihan benih, perkecambahan benih, pemeliharaan tanaman, pemberian cekaman kekeringan, pengamatan skor daun. Benih direndam di dalam air selama 2 jam dengan tujuan untuk menseleksi kualitas benih. Benih padi disterilisasi dengan menggunakan pemutih komersial $2 \%$ selama 2 menit dengan 3 kali ulangan, kemudian dicuci dengan akuades. Selanjutnya benih dikecambahkan selama 3 hari di wadah yang berisi media pasir, dan bagian atas wadah ditutup dengan kertas koran. Sebelum penanaman, tiap pot yang telah berisi tanah disiram dengan air sampai kapasitas lapang (Nio dan Ludong, 2011).

Benih yang telah berkecambah ditanam pada media tanam dalam pot yang berupa botol air mineral yang sudah disiapkan. Pada tiap pot ditanam 2 biji yang telah berkecambah, selanjutnya disiram dengan campuran air dan pupuk (10 g pupuk Gandasil D dalam $10 \mathrm{~L}$ air) sampai kapasitas lapang. Tanaman terus disiram sampai kapasitas lapang tiap 2 hari sampai mencapai tahap 2 daun yang berkembang penuh (2 fully expanded leaf), dan perlakuan akan dimulai. Sebelum diberi perlakuan, hanya satu tanaman yang dipilih untuk setiap pot untuk selanjutnya digunakan dalam penelitian (Nio dan Ludong, 2011).

\section{Hasil dan Pembahasan}

Kekurangan air mempengaruhi proses fisiologi dan biokimia tanaman serta menyebabkan terjadinya modifikasi anatomi dan morfologi tanaman. Beberapa indikator tanaman yang mengalami kekurangan air dapat ditinjau dari aspek fisiologi, anatomi dan morfologi, seperti pertumbuhan daun yang terhambat, pertumbuhan akar yang cepat, penutupan stomata, dan penggulungan daun yang umum terjadi pada tanaman Poaceae (Bahrun, 2002 dalam Kurniasih dan Wulandhany, 2009). Penurunan kehilangan air dapat dilakukan dengan cara penggulungan daun, penutupan stomata, penurunan potensial air daun, pengurangan luas daun, percepatan pengguguran daun yang selanjutnya akan mengurangi total fotosintesis dan produksi biomassa (Salisbury and Ross, 1992; Bouman dan Tuong, 2001; Adisyahputra et al., 2011; Tubur, 2011).

Penggulungan daun merupakan salah satu mekanisme drought avoidance pada tanaman untuk mempertahankan potensial air daun tetap tinggi saat kekurangan air (Bouman dan Tuong, 2001). Penggulungan daun mengakibatkan laju transpirasi menurun karena luas daun yang terpapar langsung dengan matahari menjadi lebih kecil. Penggulungan daun berkaitan erat dengan anatomi daun dan terjadi karena proses pengkerutan bulliform cell atau sel kipas (Zou et al., 2011).

Hasil analisis varians pada tingkat kepercayaan 5\% menunjukkan bahwa skor penggulungan daun pada hari ke 2, 11, dan 14 berbeda nyata (Tabel 1). Hal ini menunjukkan bahwa pada hari ke 2, 11 dan 14 faktor perlakuan yaitu pengairan mempengaruhi proses metabolisme tanaman yang mempengaruhi proses penggulungan daun. 
Tabel 1. Skor penggulungan daun padi varietas Burungan, Superwin, Temo dan Burungan dengan perlakuan diairi sampai kapasitas lapang dan tidak diairi (rata-rata \pm standar deviasi)

\begin{tabular}{|c|c|c|c|c|c|c|c|c|}
\hline \multirow{2}{*}{$\begin{array}{c}\text { Hari } \\
\text { ke- }\end{array}$} & \multicolumn{2}{|c|}{ Burungan } & \multicolumn{2}{c}{ Superwin } & \multicolumn{2}{c|}{ Temo } & \multicolumn{2}{c|}{ Ombong } \\
\cline { 2 - 9 } & DA & TA & DA & TA & DA & TA & DA \\
\hline 0 & $0 \pm 0$ & $0 \pm 0$ & $0 \pm 0$ & $0 \pm 0$ & $0 \pm 0$ & $0 \pm 0$ & $0 \pm 0$ & $0 \pm 0$ \\
\hline 2 & $0.07 \pm 0.07 b$ & $0 \pm 0 a$ & $0.21 \pm 0.11 b$ & $0.5 \pm 0.36 c$ & $0.21 \pm 0.11 b$ & $0.14 \pm 0.1 b$ & $0.07 \pm 0.07 b$ & $0.31 \pm 0.13 b$ \\
\hline 4 & $0.5 \pm 0.23$ & $0.71 \pm 0.13$ & $0.5 \pm 0.23$ & $0.71 \pm 0.35$ & $0.5 \pm 0.23$ & $0.5 \pm 0.23$ & $0.14 \pm 01$ & $0.38 \pm 0.14$ \\
\hline 6 & $1 \pm 0.26$ & $1.14 \pm 0.23$ & $1.14 \pm 0.4$ & $0.87 \pm 0.32$ & $0.79 \pm 0.28$ & $0.93 \pm 0.32$ & $0.79 \pm 0.28$ & $0.92 \pm 0.21$ \\
\hline 7 & $1.79 \pm 0.37$ & $2 \pm 0.28$ & $1.64 \pm 0.4$ & $1.36 \pm 0.33$ & $1.21 \pm 0.21$ & $1.5 \pm 0.39$ & $1.14 \pm 0.23$ & $1.08 \pm 0.18$ \\
\hline 8 & $2.29 \pm 0.34$ & $3.29 \pm 0.62$ & $1.93 \pm 0.37$ & $2.07 \pm 0.63$ & $1.56 \pm 0.25$ & $2.43 \pm 0.49$ & $1.38 \pm 0.27$ & $1.77 \pm 0.48$ \\
\hline 9 & $2.57 \pm 0.37$ & $4.14 \pm 0.72$ & $2.14 \pm 0.35$ & $2.71 \pm 0.51$ & $2 \pm 0.28$ & $4.29 \pm 0.75$ & $1.77 \pm 0.28$ & $2.85 \pm 0.53$ \\
\hline 10 & $2.71 \pm 0.35$ & $4.43 \pm 0.64$ & $3 \pm 0.42$ & $3 \pm 0.59$ & $2.29 \pm 0.34$ & $4.57 \pm 0.82$ & $2.38 \pm 0.27$ & $2.69 \pm 0.5$ \\
\hline 11 & $3.14 \pm 0.39 a$ & $7.43 \pm 0.52 c$ & $3 \pm 0.36 a$ & $4.71 \pm 0.51 b$ & $2.71 \pm 0.46 a$ & $6.71 \pm 0.51 c$ & $2.69 \pm 0.21 a$ & $6.54 \pm 0.46 c$ \\
\hline 12 & $3.29 \pm 0.35$ & $7.86 \pm 0.54$ & $3 \pm 0.36$ & $5.14 \pm 0.61$ & $2.71 \pm 0.46$ & $7.71 \pm 0.54$ & $2.38 \pm 0.27$ & $7.31 \pm 0.55$ \\
\hline 13 & $2.86 \pm 0.39$ & $8 \pm 0.55$ & $3 \pm 0.36$ & $5.71 \pm 0.74$ & $2.71 \pm 0.46$ & $7.43 \pm 0.56$ & $3 \pm 0.23$ & $7.92 \pm 0.54$ \\
\hline 14 & $4.43 \pm 0.25 b$ & $8.86 \pm 0.14 \mathrm{~d}$ & $4 \pm 0.35 b$ & $7.29 \pm 0.51 \mathrm{c}$ & $3.86 \pm 0.27 \mathrm{ab}$ & $8.57 \pm 0.23 \mathrm{~d}$ & $3.46 \pm 0.24 \mathrm{a}$ & $8.85 \pm 0.15 \mathrm{~d}$ \\
\hline
\end{tabular}

Pada awal pemberian perlakuan yaitu hari ke 2 , keempat varietas padi lokal Sulut menunjukkan respon yang berbeda terhadap lingkungan yang tidak mendukung pertumbuhan tanaman. Perbedaan ini ditunjukkan oleh perubahan bentuk daun yang awalnya tidak menggulung (sehat) yang ditandai dengan skor 0 berubah menjadi skor 1 yang memperlihatkan pinggiran daun mulai menggulung. Skor penggulungan daun pada hari ke2 setelah perlakuan lebih besar daripada 2 hari sebelumnya. Varietas Superwin memiliki skor penggulungan daun tertinggi pada 2 hari setelah perlakuan yaitu 0,5 untuk tanaman yang tidak diairi dibandingkan dengan varietas Burungan (skor 0), Temo (Skor rata-rata 0,14 ) dan Ombong (skor ratarata 0,31). Hal ini disebabkan karena varietas Superwin merupakan padi sawah yang selalu hidup di daerah tergenang air sehingga kekurangan air menyebabkan varietas ini merespon lebih cepat terhadap kondisi lingkungan yang baru ini.

Kemampuan tanaman dalam menghindar dari kekeringan akibat kekurangan air terlihat pada hari ke-3 sampai hari ke-10 setelah perlakuan. Selama 1 minggu setelah perlakuan tanaman-tanaman ini masih bertahan di lingkungan dengan ketersediaan air yang terbatas. Akan tetapi, perubahan skor tetap terjadi walaupun tidak ada perbedaan nyata untuk interaksi antara faktor pengairan dan varietas. Selama 1 minggu tanpa diairi skor penggulungan daun berubah dari skor 1 menjadi 3 dengan ujung daun yang menggulung menyerupai huruf V. Pada hari ke-10 setelah perlakuan tidak diairi, skor penggulungan daun tanaman yang tidak diairi lebih besar daripada yang diairi.

Berdasarkan uji ANAVA pada tingkat kepercayaan 5\% interaksi antara faktor pengairan dan varietas menyebabkan perbedaan skor penggulungan daun yang nyata pada hari ke-11 setelah tidak diairi. Rata-rata skor penggulungan daun varietas Burungan $(7,43)$, Temo $(6,71)$ dan Ombong $(6,54)$ lebih tinggi dibandingkan dengan varietas Superwin $(4,71)$. Di hari ke-11 sebagian besar daun menggulung membentuk huruf $U$ (skor 5). Pada saat ini, bagian ujung dan pangkal daun menggulung ke arah dalam menyerupai bentuk huruf U. Sebagian besar varietas Burungan, Temo dan Ombong menggulung seperti huruf 0 (skor 7). Kedua pinggiran daun menggulung dan saling bersentuhan tetapi belum sepenuhnya menggulung. Memasuki masa kritis dan akhir penelitian yaitu pada hari ke-11 sampai ke-14 yang merupakan akhir dari fase vegetatif tanaman, skor penggulungan daun juga berbeda nyata pada keempat varietas padi lokal Sulawesi Utara akibat kekurangan air. Pada hari ke-14 setelah perlakuan, tanaman yang diairi masih bertumbuh dengan baik dengan skor penggulungan daun berkisar antara 3 sampai 4. Sebaliknya tanaman yang tidak diairi telah menggulung penuh dari ujung sampai ke pangkal daun (skor 9). Diantara varietas padi yang tidak diairi, Superwin menunjukkan rata-rata skor penggulungan daun terendah 7,29 dibandingkan 
dengan skor pada Burungan $(8,86)$, Temo $(8,57)$ dan Ombong $(8,85)$.

Penggulungan daun merupakan suatu bentuk respon adanya peningkatan resistensi stomata untuk meningkatkan potensial air daun. Pada kebanyakan spesies, penggulungan daun hanya akan terjadi ketika kadar air menurun hingga mencapai level letal.Respon menggulung padi varietas IR28 dan KP mulai ditunjukkan pada potensial air yang tinggi yaitu -8 sampai -10 bars. Daun IR28 menggulung penuh pada potensial air 20 sampai -25 bars tetapi varietas KP tidak sampai menggulung penuh. Penggulungan daun menyebabkan penurunan luas daun yang terpapar sehingga menghambat kehilangan air dan menghindar kerusakan jaringan yang lebih parah akibat cekaman kekeringan (O'Toole and Cruz, 1980).

Hasil penelitian Tubur et al., (2012) menunjukkan bahwa respon penggulungan daun hanya terjadi pada kekeringan diawal masa pertumbuhan dengan skor daun tertinggi (skor 9) pada padi varietas IR64 (padi sawah) dan terendah oleh varietas Jatiluhur (padi gogo) dengan skor 3.0. Berbeda dengan hasil penelitian tersebut, pada penelitian ini skor penggulungan varietas Superwin yang merupakan padi sawah terendah pada hari ke14 setelah kekurangan air dan berbeda nyata dengan varietas padi gogo Burungan, Temo dan Ombong yang memiliki skor lebih tinggi. Kurniasih dan Wulandhany (2009) melaporkan diantara kelima varietas padi gogo yang dievaluasi, skor penggulungan daun varietas Sentani lebih tinggi dibandingkan dengan Mentik, IR64, Ketan Gudel dan Cempo Grondol. Sentani lebih cepat melakukan pemeliharaan potensial air daun dengan menggulung daunnya secara cepat saat terjadi kekeringan, sehingga mengurangi laju evapotranspirasi.

Penggulungan daun yang lambat, cepat dalam pemulihan (recovery) dan toleran terhadap panas merupakan karakteristik vareitas yang tahan kering (Suprianto, 1998). Terlambatnya penggulungan daun menunjukkan adanya upaya tanaman untuk mempertahankan turgor dalam upaya menghindari dehidrasi. Genotipe tanaman dengan skor penggulungan daun terendah mempunyai potensial air yang lebih tinggi (Kurniasih dan Wulandhany, 2009; Tubur, 2012). Dalam penelitian ini skor penggulungan daun padi sawah Superwin lebih rendah dibandingkan dengan padi gogo Burungan, Temo dan Ombong. Berdasarkan skor penggulungan daun, varietas Superwin lebih tahan kering daripada 3 varietas padi lokal Sulawesi Utara lainnya yang dievaluasi dalam penelitian ini (Tabel 1).

Hasil penelitian ini melengkapi beberapa hasil penelitian sebelumnya yang menunjukkan potensi tahan kering pada Superwin berdasarkan karakter rasio akar:tajuk dan rasio panjang akar seminal:tunas (Ballo et al., 2012, Nio dan Ludong, 2013), dan rasio panjang akar:tinggi tanaman
(Torey et al., 2013). Oleh sebab itu padi varietas Superwin dapat dipertimbangkan untuk ditanam di lahan kering walaupun evaluasi tahan kering yang lebih komprehensif berdasarkan karakter lain masih perlu dilakukan secara berkesinambungan.

\section{Kesimpulan}

1. Skor penggulungan daun dapat dipakai sebagai indikator tahan kering pada keempat varietas padi lokal Sulut.

2. Berdasarkan skor penggulungan daun, resistensi Superwin terhadap kekeringan akibat kekurangan air pada fase vegetatif lebih tinggi daripada Burungan, Temo dan Ombong.

\section{Daftar Pustaka}

Adisyahputra, Sudarsono, dan K. Setiawan. 2011. Pewarisan Sifat Densitas Stomata dan Laju Kehilangan Air Daun (Rate leaf water loss RWL) pada Kacang Tanah (Arachis hypogaea L.). Jurnal Natur Indonesia 14 (1):73-89

Ballo, M. 2012. Respons Morfologis Padi (Oryza sativa L.) Terhadap Kekeringan Pada Fase Perkecambahan [skripsi]. FMIPA UNSRAT. Manado

Bouman, B.A.M dan T.P. Tuong. 2001. Field Water Management to Save Water and Increase Its Productivity In Irrigated Rice. Agric. Water Manage 49:11-30.

Darusman, LK., O. Koswara, J. Wiroatmodjo, dan S. Arsjad. 1991. Pengaruh stress air dan pH tanah terhadap kemungkinan timbulnya senyawaan stress pada tanaman kentang (Solanum tuberosum L.) Forum Pascasarjana 14 (1):13-23.

Fahn, A. 1990. Plant Anatomy. 4th Ed. London, San Francisco: W.H. Freeman and Company, Butterwort-Heinemann Ltd

Fitter, A.H. dan R.K.M Hay. 1994. Fisiologi Lingkungan Tanaman. Gadjah Mada University Press, Yogyakarta.

Kurniasih, B dan F. Wulandhany. 2009. Penggulungan Daun, Pertumbuhan Tajuk dan Akar Beberapa Varietas Padi Gogo pada Kondisi Cekaman Air yang Berbeda. Agrivita. 31 (2) : 118-128.

Nio S.A. dan D.P.M. Ludong. 2011. Evaluasi indikator toleransi terhadap cekaman kekeringan pada varietas padi yang dibudidayakan di Sulawesi Utara : Ciri-ciri fisiologi. Laporan penelitian fundamental 2011, FMIPA UNSRAT.

Purwani, E.T. 2006. Pemanfaatan Informasi Prakiraan Musim BMG dalam Pengamanan Produksi di Sektor Pertanian. Direktorat Perlindungan Tanaman. Direktorat Jendral Tanaman Pangan. Departemen Pertanian. disampaikan pada Pelatihan Capable. Juli 2006. BIOTROP. Bogor. 
Salisbury, F.B. dan C.W. Ross. 1992. Plant Physiology, $4^{\text {th }}$ Ed. Wadsworth Publishing Company. California

Suprianto, E. 1998. Evaluasi Beberapa Varietas dan Galur Padi Pada Kondisi Kekeringan [skripsi]. IPB. Bogor.

Tubur, H.W. 2011. Respon Beberapa Genotipe Padi terhadap Periode Kekeringan pada Sistem Sawah. Tesis. Sekolah Pascasarjana. IPB. Bogor.
Tubur, H.W., M.A. Chozin, E. Santosa, dan A. Junaedi. 2012. Respon Agronomi Varietas Padi terhadap Periode Kekeringan pada Sistem Sawah. J. Agron. Indonesia 40 (3) : 167 - 173

Zou, LP., X.H. Sun, Z.G. Zhang, P. Liu, J.X. Wu, C.J. Tian, J.L. Qiu dan T.G. Lu. 2011. Leaf Rolling Controlled by the Homeodomain Leucine Zipper Clas IV Gene Roc5 in Rice. Plant Physiology. Vol. 156, pp. 1589-1602 